\title{
Gender Issues In Microfinance: Policy Analysis And Possible Interventions
}

\author{
Nazmunnessa Mahtab \\ \& \\ Md. Mynul Islam \\ Department of Women and Gender Studies \\ University of Dhaka
}

\begin{abstract}
Women constitute not only half of the world's population, but also sway the growth of the other half. They produce half of the world's food supply and account for $60 \%$ of the work force, but comprise $10 \%$ of the world's economy and surprisingly own less than $1 \%$ of the real estate. They have little access to productive resources and negligible control over family income. This discrimination is the consequence of gender bias which forms an inherent part of the global society. Examples from survey will validate the statement. The index ranking of 151 countries on gender inequality in addressing poverty, education, basic health, employment (income), violence and political participation, contained in various Human Development Report prepared by the United Nations Development Program since 1995 till 2003, shows that "no country treat women as well as men." Despite such investments in time and labour by women, why is there so much discrimination, inequality and why are women termed as "poorest of the poor"? The main objective of this paper is to focus on women in enterprise development in Bangladesh. However, before going into the main area, the paper tries to analyze the need and reasons for micro-enterprise development of women. The paper is divided into three main sections. The first section deals with a brief discussion on the status of women and poverty in Bangladesh. The second section focuses on women and micro- enterprise development. The third section discusses the problems faced by women in enterprise development. The fourth section focuses on the interventions required to enhance women entrepreneurship development. The last section deals with the future provisions.

The paper is prepared mainly on the basis of secondary information, review of previous research work, the author's own experience and knowledge on women enterprise on some case studies of the positive and negative effects of microenterprise of women.
\end{abstract}

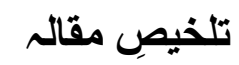

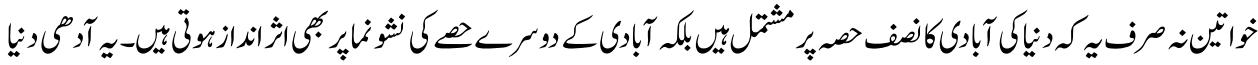

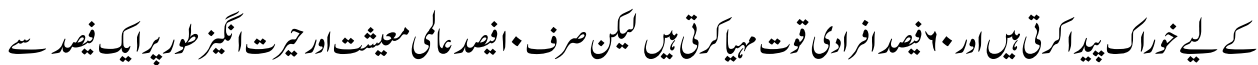

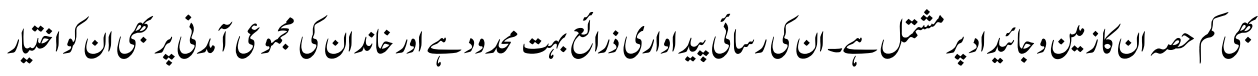

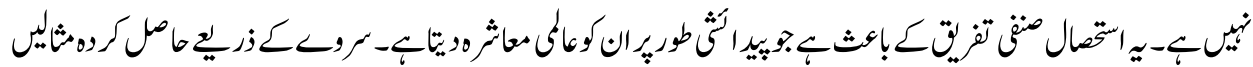




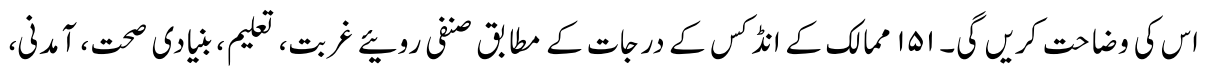

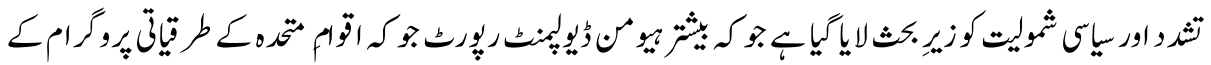

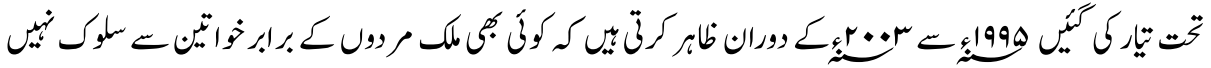

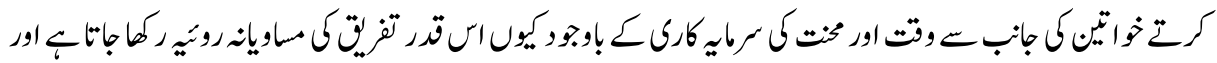

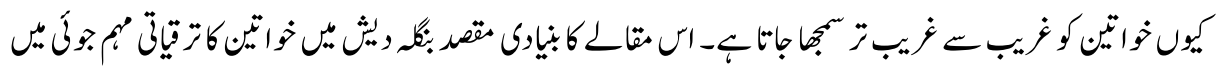

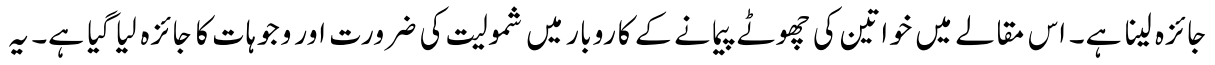

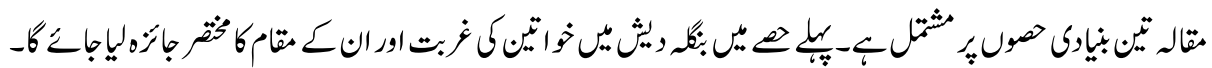

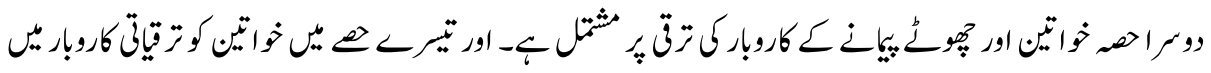

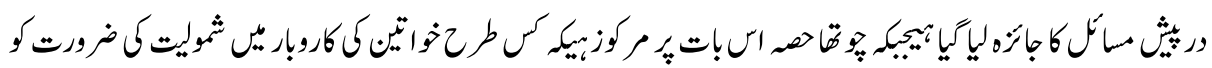

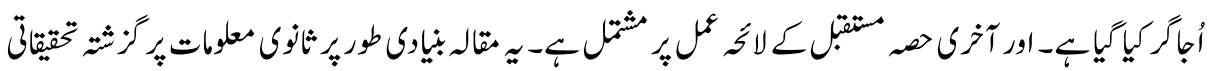

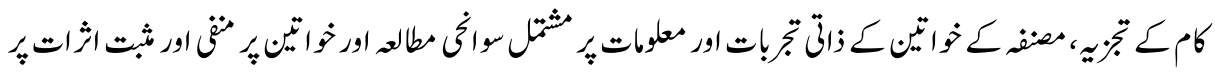

$$
\begin{aligned}
& \text { مثنز }
\end{aligned}
$$

\section{Introduction}

Over the last three decades, there has been a dramatic increase in concern with developing and adopting strategies to address the question of feminization of poverty. Women in Third World countries, like Bangladesh, face many social difficulties and economic deprivation. Social structures and the state environment are not favourable for the social development and economic upliftment of women. Despite several positive interventions and affirmative actions undertaken by the Government over the last three decades, the position of women have not improved up to the level of expectations desired by the society.

As regards employment, women in Bangladesh are far behind men. In Bangladesh about $46 \%$ of the population live below the poverty line of which two-thirds are females. According to the 1995-1996 Labour Force Survey the total activity rate was $56 \%$ for women and $89 \%$ for men. Nearly $43 \%$ women are involved in agricultural activities but $70 \%$ of them work as unpaid family labour. This is because women's participation and contribution in the economic sector has not been adequately evaluated. Women's work in the family and household economy is not being recognized as a productive activity.

Women, of course, have always worked. Today, Bangladeshi women do contribute to their household and to the country's economy. Traditionally, women have been recognized for their reproductive role and discouraged or prevented from participating in public life, including most forms of paid employment. (ESCAP). However, with 
increasing poverty and the breakdown of the supportive kinship umbrella, and also due to the demand generated by some sectors of the economy, women's participation in the labor market has been increasing during the mid 1980s. This rapid influx of women in the labor markets has become a key factor in the growing independence of women, economically, socially and legally.

Micro-credit operation is intimately related to the concepts of microfinance, poverty alleviation and micro entrepreneurship. Micro-credit has emerged as an important development paradigm, which is being used as an effective tool for poverty alleviation of about 60 million people, nearly $46 \%$ of the country's population. Out of this about 13 million people mostly women $(90 \%)$ are receiving micro-credit services. In recent years, micro-credit, in its wider dimension known as micro-finance, has become a much favoured intervention for poverty alleviation in the developing countries and least developed countries.

Bangladesh's spectacular progress is attributed to the pioneering job done by the Grameen Bank Model of micro-credit by introducing collateral free credit to the poor as a key factor for addressing the problem of poverty. With the success of Grameen Bank's program large NGOs in Bangladesh like BRAC and ASA introduced micro-credit programmes for their members. But there was bottleneck of adequate financial support and lack of continuity of donors fund for their micro-credit programmes. Under such circumstances, the Government of Bangladesh set up the Palli Karma- Sahayak Foundation (PKSF) in May 1990 as an apex funding institution to provide collateral free credit to their poor members. PKSF is the second tier funding institution operating through its Partner Organizations (POs), with focus on poverty alleviation.

\section{Historical Background: A Brief History of Microfinance in Bangladesh}

In 1971 Bangladesh emerged as an independent nation, ravaged by war and natural disaster, populated by destitute and a significant cadre of young activists full of hope, energy and commitment to reconstruction and nation-building. As the new government failed to meet the substantial challenges, even with overseas assistance, small nongovernmental organizations emerged over the 1970s to organize relief and rehabilitation through community development. As noted above, however, elite capture of resources plagued community development experiments, so targeted approaches began to be tried.

The Grameen Bank was started as an action research project in 1976, when a Chittagong University team led by economics professor Muhammad Yunus began to lend small amounts of money to poor households in a few nearby villages. Borrowers were organized into small peer monitoring groups of four or five people (soon becoming single sex groups, with a focus on women's groups) that met weekly with other groups to make 
loan repayments. Demand for credit grew rapidly and repayment rates were good, so the project was able to secure loans for on-lending from the state-controlled Bangladesh Bank and other commercial banks. In 1984, the Grameen Bank became a governmentregulated bank through a special government ordinance, and remains the only body regulated in this way.

Over the next two decades NGOs grew in number and scale and by the early 1990s the experiences of BRAC, Proshika and ASA, as well as the Grameen Bank, dominated development discourse in Bangladesh. The early 1990s in particular was a period of rapid expansion of access to microcredit. Procedures were by then established and standardized, and computerization became more common, allowing the MFIs to intensify disbursement and repayment monitoring.

The Grameen Bank and NGO MFIs used donor funds, and, increasingly, member savings and interest payments, to replicate new branches across the country. During this period, a wholesale financing institution (PKSF) also emerged. But by the mid-1990s it seemed that the very success of .first generation. MFIs led by the Grameen Bank were hindering the development of new and different approaches to microfinance (Hulme in Rogaly, 1996). The movement of the integrated, socially-focused programming of ASA in particular, but also of BRAC and other NGOs, towards that of the finance-minimalist Grameen Bank was clear and noted by many Zaman (2004:51) notes that the benefits of a narrow focus on microcredit during the expansion phase was that it kept costs low, operations transparent, and management oversight relatively straightforward.

From the mid-1990s, however, a range of .second generation innovations began to emerge, as it became increasingly clear that the poor required a wider range of financial services; that the existing services, particularly savings, needed to be made more flexible; that the needs of vulnerable non-poor micro- and small entrepreneurs were not being met; and that the poorest were often excluded from microfinance. This change in focus was based on feedback from the field in Bangladesh and internationally, and a large amount of research, conducted both in house (by BRAC and Proshika researchers in particular), as well as by national and international academics and consultants. The emergence of Safe Save in 1997 as an experiment dedicated to investigating the possibilities of savingsled, individual-oriented microfinance was a forerunner of the period.

\section{Microenterprise Movement: Bangladesh Perspective}

The focus on microenterprises is an attempt to give value to the interests of some of the poorest women in Bangladesh, especially for the women who are doing their best to improve the well being of their household through a micro business venture. Indeed in some instances, the efforts of women involving in micro-enterprises are to seek self 
employment as a response to bringing about change in their existing conditions of poverty.

The microenterprise movement, both internationally and domestically has been viewed as an important economic development strategy for economic growth. This paradigm is based on the premise that gender discrimination is an economic phenomenon and, therefore, the generation of employment and income through micro-enterprises would empower women.

Micro-enterprise can be defined as a tiny business usually with one owner started by the poor in cities, towns and villages, commencing with minimal investment and not requiring a formal establishment. Owners of micro enterprises do not generally use formal financial institutional channels for credit or any other financial transactions. Employees, if any, are usually or family members who are easy to monitor.

Generally, microenterprises of NGO- MFIs are the expansion of income generating activities (IGAs) of graduate or progressive borrowers. Most of the micro-enterprisers go into business of their own after having worked in the same sector for someone else for a number of years. In this capacity they have the opportunity to build their technical, managerial and marketing skills to the point where they are prepared to start on their own. In doing this they save funds to launch small businesses, which may start as a parttime activity, and gradually they may join targeted micro-enterprise programs of NGOMFIs. Another category of micro enterprise are developed by women on their own initiative, for starting a small business of their own. The types of micro enterprises operated by women are of the following categories: (Mahmud, 2005).

A. Traditional: Traditional crafts and cottage type activities such as handicrafts (jute, grass, cane and bamboo works, weaving, sewing, knitting, poultry and cattle Raising, making of coir mats and ropes, making chira and muri and post-harvest Agricultural activities.

B. Non -Traditional: Rural and informal non-farm activities such as trade and commerce, transport and construction.

C. Household or Family Trade: Food processing, tailoring, chanachur production, grocery stores, poultry farm, cow rearing, sweetmeat shops and restaurants.

For a regular credit program the range of collateral-free credit is between Tk. 2000-Tk. 20,000 for one year. As graduate borrowers move on and gain confidence in handling loans, their average loan amount increases. Loan for micro-enterprise range between Tk.20,000 to Tk. 2, 00,000. Although, the promotion of micro-credit linked microenterprises of women group members of NGOs have not contributed to additional 
employment opportunities, women enterprise development paradigm has been seen as making a positive contribution to economic growth thus improving women's social position. On the other hand it has been argued that micro-enterprises do not help to augment the income and employment of women labourers, but accentuate the process of women's labour exploitation. This finding has been made evident by studies concentrating on the experiences of sample households engaged in certain microenterprises managed by women themselves. For example many women who have started their own micro-enterprise in the textile sector (for example, making clothes,) usually employ poor women to work for them at a very low cost. The profile of these women indicates that they belong to the age group between 30 to 45 . It has also been found that women with a relatively poor socio-economic background are interested in such income generating activities under micro-enterprises. Their educational background showed that most of them have either Secondary School Leaving Certificate (SSC) or even lower than that. Often these women have to work for more hours than required without getting payment for the extra work. There is often the risk that in women's micro-enterprise schemes, the benefits of the activities, including income earned and assets accrued, will not necessarily be controlled by women for expenditure on their own and basic family needs. For example, studies conducted on empowerment based on income earned from micro-enterprises indicate that a significant portion of the credit given to women was actually controlled by men.

Economic hardship was found to be the main push factor for women working in the micro-enterprises. The initial driving force to start micro enterprise for the majority of women micro-credit borrowers is to supplement their existing, insufficient, family income to meet the basic necessities of life. PKSF's experiences from the field revealed that among the poor marginal women involved in family businesses, the percentage of forced women in micro-enterprise is quite high. These women are compelled by circumstances, that is, the prolonged illness or death of the head of the family, and abandonment or divorce by the husband are the main causes for women's involvement in family businesses.

\section{Women Entrepreneurship Development}

Women entrepreneurs may be defined as the woman or a group of women who initiate, organize and operate a business enterprise. In business the entry of women is a relatively new phenomenon. A woman may start her own business due to several reasons. She may not be able to find a job in the market place or she may not be able to work outside her house. In the feminist empowerment paradigm, the dominant development aim is the eradication of gendered resource and power inequalities and women's empowerment. 
Entrepreneurship offers a number of potential advantages for women. Firstly, where women have been able to set up economic activities, this success has helped many women to build up an independent resource base. Recently, in Bangladesh this is particularly important as women are widely expected to provide substantial support for themselves and their children. Some uprising young business women in Bangladesh mentioned their ability to be financially independent as the most important change in their lives in recent years. Entrepreneurship has enabled some women to have an income which they may control themselves and contribute to the household and improve their status. Women entrepreneurship is also seen as an attractive to wage employment.

More contentious is the question of home working. Women's self employment through entrepreneurship has been promoted, and is often being preferred by women themselves because of the possibility of working from home, and thus combining income earning activities with unpaid domestic work. Reasons given by women for becoming entrepreneurs include: personal ambition; creativity; a desire for independence; to be one's own boss; self realization and an ambition to improve the quality of working conditions; to raise economic returns; and to develop a flexibility that caters to the needs of family responsibilities. For many women, working as managers in larger organizations, the frustrations of the glass ceiling effect has motivated them to look towards business creation.

The expansion of women entrepreneurship, coupled with women's increasing gender awareness and increasing influence of women's movements, has led to the formation of Bangladesh Women's Entrepreneurs Associations. These have helped in increasing the visibility of women in economic decision-making, although influence is still far from equal to that of men.

Another very recent phenomenon in Bangladesh is the management of family business by the wives of industrialists. Previously, the wives were designated as Directors or shareholders of large companies, as "hidden transcripts", or silent partners. But nowadays, it has become evident the wives of the big industrialists are holding the positions of Directors and are being involved in the entire major decision making process of the businesses. Today, in Bangladesh we even find educated daughters taking over the responsibility of family businesses being confident and assertive and aiming towards achieving empowerment.

\section{Constraints/ Barriers to Women Enterprise Development}

In Bangladesh, although there is an increase of women entrepreneurship at the top, women are mainly clustered in a narrow range of low investment, low profit activities for the local market. Institutionalized inequality at the macro and household levels seriously 
limits the ability of women entrepreneurs to take advantage of the opportunities offered by market growth.

- Low Investment;

- Low Profit Activities;

- Slower Growth Rates of Women Owned Enterprise;

- Institutionalized Inequality at the Macro-level and Household levels;

- Women's Restricted Access to Property, Income and Credit;

- Institutionalized Discrimination in Legal Systems;

- Access to and Control Over Resources ;

- Gender based Social Impediments;

- Unfavourable Infrastructure and Support Systems.

From all these constraints, limited access to productive resources, (particularly capital, labour, time and technologies), transport constraints, lack of market knowledge, lack of basic literacy and numeracy skills can restrict the capacity of women to participate effectively in business activities. For women, lack of access to and control over property constitute serious barriers. In many countries, including Bangladesh, women are seen--both in customary and formal legal systems - as dependents of men and subject to their authority as fathers, husbands, brothers and even sons. In Bangladesh, women have independent legal rights, but the traditional systems of marriage and inheritance coupled with corrupt and expensive legal systems, make it difficult for most women to enforce their legal rights. Although in both traditional Hindu and Muslim law, property was given to women on marriage, these customary rights have been increasingly eroded and exorbitant dowry payments to husbands and in-laws have become the norm. This lack of formal ownership rights in property creates additional barriers to registration of women's businesses. The lack of formal ownership rights in property is also a central factor in limiting women to those businesses and trade which require little start up capital.

Researches have also shown that access to start up, acquisition and growth of capital remains a big obstacle for women business owners. Women start business with less capital than men. This is because women start businesses in service areas which require less capital investment. However, evidence also suggests that women are also outside the established financial network. Sometimes, experienced women entrepreneurs face greater difficulties than men in obtaining loans, even when they have collateral, business plans and plenty of experience. Even when women receive credit they have to prove themselves in order to get their business skills recognized by the banks. Women also face greater problems obtaining capital and discrimination by male bank managers, many of whom fail to understand women's different career patterns. 
Although women may enjoy some marketing advantages in products and services where the majority of customers are female, in most markets they face a range of types of discrimination which prevent them from taking advantage of many opportunities opened up by free market economic system. Market information systems about inputs and marketing tend to be targeted to men. As the president of the Bangladesh women Chamber of Commerce described how her business plan was affected as she was not aware of the market demand of her product.

Adherence to purdah norms continues to constrain women's public mobility, limiting their choice of enterprise and their ability to carry out transactions in the market place.

Women's ability to enter new markets is seriously limited by lack of technical skills and experience. Even in female preferred industries women lack managerial and business skills, and the skills they have are often undervalued.

Social attitudes concerning the value of traditional women's work activities and their potential abilities also limit their participation rates and ultimate commercial success of women entrepreneurs. Rural women frequently have primary responsibility for agricultural production, in addition to domestic responsibilities and childcare. These responsibilities place heavy demands on women's time, and micro-enterprise activities can potentially increase the workload of women. These problems affect women's ability to expand their enterprises.

\section{Impact Analysis of Microfinance Projects}

Impact analysis of microfinance regarding women's small business has not been analyzed yet with a large scale and regularly or it's a very current issue. It is an important issue to analyze to improve women's economic and social empowerment through their economic independency. There have been many impact studies conducted on microcredit programs beginning mid-1980s through 1990s. The objectives were to clearly and verifiably prove the financial and economic impact of microcredit programs on the lives of the poor as well as level of reduction of poverty. However, later on it has been taken for granted that if poor people can be reached with financial services, especially credit, they will prudently utilize the monies for investments and other purposes to uplift their poverty situation.

A study has been conducted by USHA- Unity for Social and Human Action a national private development organization. The main goal of this organization is ensure gender equality based society and women's empowerment. They have directed a project named A collective Drive to Engender the Process of Women's Empowerment (CDEPWE) to establish women's friendly loan and main objective of this project was to establish 
women as a small entrepreneur. This project has provided employment to numerous women in helped in starting their own business in handloom products. On the basis of success of previous project they have started another project named Gender Responsive Approach to Women Rights and Economic Empowerment (GRAWHEREE) to ensure women's economic empowerment and security of human rights. Economic empowerment has been achieved by promoting employment to poor women by providing them with loan to start their own business enterprises.

The pioneering impact study on the microcredit program of the Grameen Bank was by Mahbub Hossain (Hossain, 1988) who evaluated it using the indicators like reaching the target groups, size of loan disbursed, loan utilization, accumulation of capital, generation of employment, and income, and poverty status, and used 'before' and 'after' as well as comparison between borrowers and non-borrower control groups to see the impact of microcredit. This was conducted in a backdrop of skepticism about the success of Grameen Bank and whether the poor borrowers really invest in the loan and actually earn enough to repay the loan as well as enhance family income.

A follow-up study was done on Grameen Bank (Rahman, 1986) that reported similar increase in income of the borrowers and found that borrowers selling marketable goods faced no problem of demand constraints. Besides, it reports that "with the expansion of Grameen activities, the rural economy is getting commercialized and more people, especially the borrowers are becoming job-specific."

A number of important studies have been conducted on the programs of the Palli KarmaSahayak Foundation and its partner organizations (microfinance institutions that receive loan from PKSF to lend on to the poor). Here I will discuss two studies Rahman (1996) and BIDS (2001). Although the methodologies applied in these two studies are somewhat similar to other impact studies but the importance of the two studies is that both measured impact of microcredit from smaller microcredit institutions, which follow Grameen Bank model, to show that impacts of income and other indicators are similar. This shows robustness of the microcredit system that has been successfully replicated to reach millions of poor left outside the Grameen Bank or a few large organizations. The smaller MFIs replicated the management system and showed that if poor were reached with financial services they could use them efficiently irrespective of sources. Rahman (1996) analyzed the impacts of microcredit using cross-sectional comparison of households who had borrowed and those who had not. A stratified random sampling method was followed for selection of MFIs of different size: small, with less than 2000, medium with members between 2000 and 3000 and large with members above 3000. Eight (8) partner MFIs were randomly selected by allocating proportion to the number of partner MFIs in each three categories. For each selected partner MFIs, 40 households were randomly selected from the list of 3 types of members: the non-borrowers, those who borrowed only once 
and those who borrowed for more than once. Forty (40) households were selected to give a reasonable size of sample in each stratum and the total sample was 960 . A survey was used among the selected households using a structured questionnaire. It was a preliminary study only after two years of PKSF's operations.

\section{Possible Interventions}

Get the confidence of MSEs As seen above, the failure to try training is the most significant obstacle. Devices can be used to encourage MSEs to try training. Private trainers find that the most effective way to get the confidence of potential trainees is the possession of technical skills (FIT Resources Ltd., 2002). Word-of-mouth seems to be effective in conveying reliable information in this respect. Would it be possible for intervention to disseminate quality information that people find as reliable as word-ofmouth? Not only information flows, but other training marketing tools also could be developed, such as training exhibitions and success stories of ex-trainees.

Reduce upfront payments Different payment arrangements also encourage MSEs to try training that private trainers offer. For instance, a trainer in Kenya successfully increased the number of trainees by offering an arrangement whereby trainees paid one tenth of the total fee prior to training sessions and the remainder upon completion of the training.

Discounting fees is another option. Indeed, training vouchers are used for this purpose. Intervention could also aim to stimulate the supply of more affordable training by establishing business relationships that are expected to deliver embedded training.

To increase the retention rate A retention rate relies mainly on how satisfied trainees are with the training in which they have participated. If a retention rate of training is not high, it could be evidence that something is wrong with the quality of the training.

Get information flows to improve quality The fact that word-of-mouth is the main means of promoting training courses seems to be the only thing that currently makes trainers quality conscious. Interventions could play a major role in improving information flows, both in terms of quantity and quality, from MSEs to trainers. Through this, training quality is likely to be improved. It is actually what is intended in training voucher programmes. By getting feedback from trainees, it has been observed that trainers do adapt existing training and/or invent new training. This function of information flows is imperative for market development, as it ensures training quality, therefore high retention rates, which is one of the important elements leading to development of the training market. 
Directly improve quality of training supply Another way to ensure training quality is to implement training of trainers (ToT). In the context of MSE development, it sometimes means training existing trainers to instil MSE-oriented business attitudes and skills.

There are two key factors of success learned from the FIT experience in ToT. Firstly, the selection of trainers to be trained is crucial. They themselves should be entrepreneurs with a strong interest in training as business. It should also be noted that one of the gains appreciated by trainers participating in ToT is the opportunity to network with other trainers. By such networking trainers can upgrade their knowledge on market needs, exchange tips for successful training, which is expected to lead to better quality training (for example, Mathuva et al., 1999).

Interventions could choose which elements from the three to take on, depending on the development stage of a market concerned. As has already been mentioned, one possible way of intervention with the three key elements is a voucher program. It can promote two-way communication between trainers and MSEs, with vouchers offering temporary discounts. There are several reports describing voucher programs, many of which are still ongoing (for instance, see Goldmark et al., 2001). However, it has not yet been shown conclusively whether voucher programs can successfully create a sustainable training market.

To increase awareness: Information flows from trainers to MSEs The first step towards market development is to inform MSEs of the training available. The amount and quality of information can be reinforced by interventions, as those means currently employed by private trainers are very limited. As mentioned earlier, effective channels may differ from place to place and also from one MSE segment to another. An interesting example is that training voucher programs are very effective in disseminating information on training to MSEs.

\section{Areas of Microenterprise Development}

Depending on number of factors ranging from landholdings, subsidiary occupations, agro climatic conditions and socio-personal characteristics of the rural and urban poor women and their family member the areas of micro-enterprise also differ from place to place. The micro enterprises are classified und three major heads:

1. Micro enterprise development related to agricultural and allied agricultural activities like cultivating vegetables and seed production. Some more areas can be like dehydration of fruits and vegetables. 
2. Micro-enterprise development related to household based operations like weaving, bakery, petty shops, food preparation and reservation.

3. Micro-enterprise development related to livestock management activities like dairy farming can be an important area in which women can utilize both her technical skills and raw materials to earn substantial income and small scale income agro processing units.

\section{Success Story: Women can be the Source of Change}

A mother of three, Amena Begum ${ }^{1}$ became widow at the age of 29 when her husband lost the battle against a kidney disease. Anyone in her position would have ended up working as a household maid, but it was with determination and hard work that she established herself as a young entrepreneur.

'I always dreamt that I would be one day growing up and become an entrepreneur and set up my own business where people will get a chance to work' said Amena. She learnt tailoring from her mother at an early age and took part in training on cutting and stitching ladies clothing. She had to quit her education and could not sit for SSC exams as she was pregnant with her first time. Initially she made sleepwear for women. She started taking sewing orders from neighbours to make money to support her family. 'Some customers ask her o put some designs on their dresses, and they loved it. Others would see my products and place orders. It soon become too much to handle on my own'. She took a loan of 50,000 taka from B'YEAH and paid back some loans and invested the rest in the business. She said 'I collect samples and sometimes unstitched fabric from different retailers. I never miss a delivery deadline, which gives my customers confidence and helps my business grow'. Today she is confident, self sufficient woman who raise three sons, contribute financially to her parents and fulfill her responsibilities by being a mentor to others.

Economic empowerment of women by micro entrepreneurship led to the empowerment of women in main things such as socio-economic opportunity, property rights, political representation, social equality, personal rights, family development, market development, community development and at last the nation development.

\section{Challenges}

1. Financial problem Inadequate starting capital is one of the main problems for the women entrepreneurs in Bangladesh. Generally, women start their business with limited capital accumulated from family savings and the relatives and other sources. For bank loans women need to put collateral except those loans coming from MFIs. Unfortunately, they do not have enough fixed capital to put as collateral or a 
guarantor to get a small loan from the bank. Hence, government has to take some risk of distributing collateral free bank loan to the SME entrepreneurs particularly for women entrepreneurs. On the other hand, bank charges around 13\% for SMEs loans and $10 \%$ for women entrepreneurs which is higher compared to neighbouring countries (India charges 5 to 7\%), thus making it difficult for the sustainability of MSMEs in a competitive global market (Abdin, 2010). It is suggested to have single digit bank interest rate for MSMEs.

2. Lack of market information Lack of market information is also one of the major problem for women in Bangladesh. They lack of information on where, what price and when the product should be sold. They do not know how to get domestic, as well as export market access. Even they lack knowledge of using market promotion activities. Thus, government should take the lead in promoting MSME products at home and abroad.

3. Poor infrastructure and utility supply Infrastructure facility is miserable in most rural areas of Bangladesh. The supply of electricity and gas are not available in many rural and even sub-urban areas. Hence, existing MSMEs are suffering badly due to load shedding of electricity and gas. So, government should improve the infrastructure and utility services in considering the need of MSME sector.

4. Traditional technology SME owners generally use local technologies to produce goods but these are not productive enough to fulfill market demand, produce quality/ beautiful products to compete with the international products available in the local market. As a result, SME entrepreneurs are losing their livelihood due to poor technical know-how. Immediate actions should be taken for replicating global success stories in SME sector of Bangladesh.

5. Lack of skilled/trained manpower there are no agencies, even not a single special institution in Bangladesh to produce qualified graduates or trained manpower that can serve as entrepreneurs. Basically to create entrepreneurs no hard and fast facility is required; but for an effective entrepreneurship generation, entrepreneurship education is necessary. The statistics proves that Bangladeshi labours are low productive (Abdin, 2010). So, training for the existing manpower is essential for greater output.

6. Complicated bureaucratic procedures Starting a manufacturing plant needs a series of license, registrations and clearances. For example to start an SME requires: (a) Trade license issued by the local government office (UP Chairman, City Corporation office), (b) trademark registration register by the Office of Patent, Design and Trademark Register under the Ministry of Industry, (c) Tax Identification Number (TIN) from NBR or Income tax office under Ministry of Finance, (d) value added tax (VAT) registration from the same authority, (e) Membership of any trade body 
(district chamber or sectoral association), (f) import registration certificate from Ministry of Commerce, (g) environment clearance from the Ministry of Environment, (h) fire clearance from the Fire Bridget and many more. Completing all these formality is not so easy and every desk needs bribe for proper passing on of the file (Abdin, 2010). This time consuming and corruption promoting system should be made easier.

7. Product Innovation The real challenge for the future of women micro enterprises lies in meeting the need for innovation and diversification in delivery methods and the introduction of new innovative products.

\section{Future Options}

- Develop Gender Sensitivity vis-vis Participation of Women in Micro Enterprise Development;

- Examine the Processes of Gender Inequalities and their Dysfunctionality affecting the Participation of Women in Micro Enterprises;

- Understand the Processes of Promoting Women Entrepreneurs and Learn Designing and Conducting Enterprise Development Motivation Training for them;

- Be Able to Explore Various Learning Mechanisms to set up Micro-Enterprises and update the Methods of Managing Activities, Develop Tools and Instruments for Effective Monitoring and Evaluation of Promoted and Successful Entrepreneurs.

- Training and support need for micro-enterprise projects, in both the microfinancing (Management of savings and credit) and micro-enterprise development (small business and technical training) areas.

According to the International Fund for Agricultural Development (IFAD), there are four key criteria for micro-enterprise development schemes aimed at poor rural women, which can both improve demand for credit and reduce the risks of indebtedness. These are:

- Modest Financial Investment;

- Low Investment Risk;

- Short Gestation Period between Investment and Generation of Regular Income;

- Availability of Local Markets.

\section{Conclusions}

Of the estimated 1.3 billion people living in poverty, more than $70 \%$ are women (UNDP, 1995). The feminization of poverty is a direct consequence of women's unequal access to economic opportunities. In recent years, micro-financing for women's small and micro- 
scale enterprises has been an effective way to promote and support women's selfemployment and access to credit. The promotion, financing and strengthening of microenterprises was also highlighted in the Beijing Platform for Action as an important way of increasing the productive capacity of women, and breaking the "cycle of poverty." (Platform for Action, 1995)

Micro-enterprise development has, in some circumstances, contributed positively to women's empowerment and helped extremely poor women survive economic crisis in the short term. However, certain structural issues that are far more pertinent to the long term problem of women and poverty have been ignored. These are: agrarian reform; programs favouring export production (typically male dominated) over subsistence crops (typically female dominated), and trade agreements structured in the interests of multi national corporations.

Entrepreneurship is a Herculean task which needs to be fraught with struggle, entailing both risks and profit. Women have to go through certain stages in setting up an enterprise and face challenges, irrespective of gender based social impediments like social stigma, unfavourable infrastructure, support systems, etc. which block their entry and reduce their pace of growth. Removing these impediments in the existing set up of micro-enterprise development has assumed a critical significance for the economic development pf women. The need today is to help women overcome these blockades and draw maximum participation from them to set up micro-enterprises, which will help them, achieve selfreliance, and ultimately empower them and place them at par with their male counterparts in all spheres of life.

If remedial measures are taken to remove impediments, micr0-enterprises may trigger an economic breakthrough and maintain economic growth. Derived demand for business development services (BDS) are emerging and in response, service providers are progressing slowly from felt needs. Broadly speaking, the major needs of these services are credit, training, information, technology, marketing and consultancy. The existing training arrangements for female micro-entrepreneurship development are inadequate and have much scope for quantitative and qualitative improvement.

Microfinance organizations have played a great role in the fight against poverty of women in Bangladesh. However, if we really want to promote women entrepreneurship, a number of additional measures need to be taken. Derived demand for business development services needs to be addressed. The growth of small and medium enterprises can only occur with proper policy measures, innovative financial products, strengthening the macro economic situation, building awareness and a positive attitude among micro-entrepreneurs about quality and environment and increasing the supportive role of banks towards women. 


\section{References}

Abdin, M. J. (2010). Bangladesh's SMEs facing so many challenges, the independent, available at: http://theindependentbd.com/paperedition/ others/panorama/2385bangladeshs-smes-facing-so-manychallenges. html (accessed on 27 November, 2012)

Adams, D. W.; Graham, D. H.; and von Pischke, J. D. (1984). Undermining rural development with cheap credit. Boulder: Westview Press.

Afrin S, Islam N, Ahmed SU (2008). A Multivariate Model of Micro Credit and Rural Women Entrepreneurship Development in Bangladesh, Int. J. Bus. Manag., 3 (8): 169-85.

Ahmed, S. (2003). Microcredit and Poverty New Realities and Issues, Journal of Bangladesh Studies, USA.

Ahmed, S. and M.A. Hakim (Ed.),(2004). Attacking Poverty with Microcredit, Palli Karma -Sahayak Foundation (PKSF)/The University Press Ltd. (UPL), Dhaka.

Alamgir, Dewan A.H. (1996). Financing the Microfinance Institutions: The Experience of Palli Karma Sahayak Foundation in Bangladesh, PKSF, Dhaka, Bangladesh.

Bangladesh Institute of Development Studies (BIDS), (2001). Final Report on BIDS Study on PKSF's Monitoring and Evaluation System (MES), October, Dhaka.

Bhattacharya, Debapriya (1990). Rural Poverty Alleviation Through Non-farm Employment Programs, Final report, BIDS, Dhaka, 1990.

Hoff, K., Braverman, A., and Stiglitz, J. (eds.) (1993). The economics of rural organization: theory, practice and policy. New York: Oxford University Press.

Hulme, D. and Mosley, P. (1996). Finance against poverty, Volumes I and II. London/New York:Routledge.

Kabeer, N. (1998) .Money can.t buy me love?.? Re-evaluating gender, credit and empowerment in rural Bangladesh. (IDS Working Paper 363) Brighton: Institute of Development Studies,University of Sussex.

Kabeer, N. (2002) We don.t do credit: Nijera Kori social mobilisation and the collective capabilities of the poor in rural Bangladesh. Dhaka: Nijera Kori. 
Kayemuddin, M (1992). A study on the impact of ASA Microcrdit, ASA, Dhaka, 1992.

Khandker, S. R. (2005) Microfinance and poverty: evidence using panel data from Bangladesh. World Bank Economic Review, 19: 263-286.

Mahmud, P. (2005). Emerging Women Micro-Entrepreneurs in Bangladesh: The Missing Middle, in Isabelle, G. and Jane, P. eds. Microfinance Challenges: Empowerment or Disempowerment of the Poor? Institut Francias de Pondichery, India, pp 183192.

Mayoux, L. (1998) Women.s empowerment and micro-finance programmes: approaches, evidence and ways forward. Open University Development Policy and Practice Working Paper No. 41.

Palli Karma -Sahayak Foundation (PKSF) (2003). Report of the International Seminar on Attacking Poverty with Microcredit", Dhaka.

Rahman, A. (1986). Demand and Marketing Aspects of Grameen Bank, Grameen Bank, Dhaka, 1996.

Rahman MW, Luo J, Xiaolin W, Ahmed S (2011). The Synthesis of Grameen Bank, BRAC and ASA Microfinance Approaches in Bangladesh, IPRCC working paper series.

Rahman MW, Parvin L (2007). Credit Program of ASA: Impact on Poverty Reduction in Some Selected Areas of Mymensingh District. J. Banglad. Agric. Univ., 5(2): 429-436.

Rahman, R. I. (1996). Impact of Credit for Rural Poor: An Evaluation of Palli Karma Sahayak Fundation's Credit Programme, Working paer no. 143, BIDS, Dhaka, Bangladesh.

Rahman, R. I. (2000). Poverty An alleviation and Empowerment Through Microfinance: Two Decades of Experince in Bangladesh, Research Monograph No. 20, BIDS, Dhaka.

Rogaly, B. (1996). Micro-finance evangelism, destitute women., and the hard selling of a new anti-poverty formula. Development in Practice, 6 (2), 100-112.

WED (2001). Economic Policy Paper on Women Entrepreneurs in Bangladesh, Dhaka Bangladesh. 
Zaman, H. (n.d.) Microfinance in Bangladesh: growth, achievements, and lessons. Chapter 4 of Scaling Up Poverty Reduction. Case Studies in Microfinance. Washington DC: CGAP/The World Bank, 2004. http://www.cgap.org/docs/ CaseStudy_scalingup.pdf

Source: The Daily Star, November 23, 2011. Business page.

Nazmunnessa Mahtab is Professor in the Department of Women and Gender Studies, University of Dhaka, Dhaka-1000, Bangladesh.

Md. Mynul Islam is Lecturer in the Department of Women and Gender Studies, University of Dhaka, Dhaka-1000, Bangladesh. 